\title{
Cloning, DNA nucleotide sequence and distribution of the gene encoding the SEF14 fimbrial antigen of Salmonella enteritidis
}

\author{
Claude Turcotte and Martin J. Woodward*
}

Molecular Genetics Unit, Central Veterinary Laboratory, New Haw, Addlestone (Weybridge), Surrey KT15 3NB, UK

(Received 13 October 1992; revised 21 January 1993; accepted 24 March 1993)

\begin{abstract}
Monoclonal antibody 69/25, specific for the Salmonella enteritidis fimbrial antigen (SEF14), was used to screen a pUC-based $S$. enteritidis gene library and a positive clone was identified. Subcloning experiments demonstrated that a 584 bp DraI DNA fragment was the minimal chromosomal segment capable of directing SEF14 antigen expression. Western blotting of Escherichia coli recombinants identified a gene product of $M_{\mathrm{r}} 16000$ as a precursor to the $M_{\mathrm{r}} 14300$ mature fimbrial subunit protein. The DNA nucleotide sequence of the DraI fragment was determined and was shown to contain a single open reading frame with two potential f-Met start codons and a hydrophobic signal sequence. Downstream of a putative peptidase cleavage site, the deduced amino acid sequence showed considerable homology with the $\mathrm{N}$-terminal amino acid sequence of what was originally described as the type 1 fimbrial subunit of Salmonella enteritidis and later redefined as SEF14. The gene encoding SEF14, designated as sefA, was shown to be limited in distribution to Salmonella blegdam, $S$. dublin, $S$. enteritidis, $S$. gallinarum, S. moscow, S. pullorum, S. rostock, S. seremban and S. typhi, all belonging to Salmonella group D. However, expression of the SEF14 antigen was limited to $S$. dublin, $S$. enteritidis, $S$. moscow and $S$. blegdam. The nucleotide sequence of the sefA gene shared no homology with the Salmonella fim $A$ gene encoding type 1 fimbriae, and these genes showed distinct patterns of distribution within salmonellae.
\end{abstract}

\section{Introduction}

Fimbriae are surface appendages found on many species of Enterobacteriaceae which often display adhesive properties (Duguid \& Old, 1980; Parry \& Rooke, 1985; De Graaf \& Mooi, 1986). Some fimbriae are considered virulence factors because they initiate adherence, which is the first step in the colonization of host mucosal surfaces (Pearce \& Buchanan, 1980; Korhonen et al., 1982; Finlay \& Falkow, 1989; Johnson, 1991; Krogfelt, 1991). Fimbriae are classified according to their morphological and cell-binding properties (Duguid \& Old, 1980; Pearce \& Buchanan, 1980; De Graaf \& Mooi, 1986). Type 1 fimbriae are rigid organelles of $7 \mathrm{~nm}$ diameter which mediate $\alpha$-D-mannose-sensitive agglutination (Abraham et al., 1988; Clegg \& Gerlach, 1987). These fimbriae are considered ubiquitous amongst the

*Author for correspondence. Tel. (0932) 341111; fax (0932) 347046.

Abbreviations: IEM, immunoelectron microscopy; mAb, monoclonal antibody.

The nucleotide sequence reported in this paper has been submitted to GenBank and has been assigned the accession number L03833.
Enterobacteriaceae (Clegg \& Gerlach, 1987; Buchanan et al., 1985). DNA sequence analysis of the type 1 fimbrial antigen genes of $S$. typhimurium (Purcell et al., 1987) indicates a monomeric protein unit of $M_{\mathrm{r}}$ approximately $17000-18000$. It is assumed that type 1 fimbriae are likely to display antigenic heterogeneity (Nowotarska \& Mulczyk, 1977; Salit \& Gotschlich, 1977; Buchanan et al., 1985; Old \& Adegbola, 1985; Clegg et al., 1987). Indeed, DNA hybridization studies have shown considerable nucleotide sequence divergence amongst type 1 fimbrial subunit sequences of Enterobacteriaceae (Buchanan et al., 1985). Other major classes of fimbriae reported in Salmonella are type 2, morphologically similar to type 1 but which do not agglutinate erythrocytes (Duguid et al., 1966), and type 3, flexible structures of 3-5 nm diameter which mediate mannoseresistant haemagglutination (Duguid \& Old, 1980). These classes of fimbriae have been described on only a few Salmonella serotypes but evidence for their role in pathogenesis is growing (Duguid et al., 1976; Hornick et al., 1991; Krogfelt, 1991; Collinson et al., 1992; Tesh \& O'Brien, 1992).

Thorns et al. (1990) produced a panel of monoclonal antibodies (mAbs) to $S$. enteritidis using a mouse 
immunization protocol designed to elicit an antibody response primarily directed against surface antigens. Immunoelectron microscopy demonstrated that one $\mathrm{mAb}$, designated $69 / 25$, bound specifically to a fimbrialike structure, designated SEFA, but not to type 1 fimbriae, which were also present on the cell surface of $S$. enteritidis. Analysis of the fimbrial antigen indicated a fimbrial subunit of $M_{\mathrm{r}} 14300$ (Thorns et al., 1990). Three discrete fimbrial antigens have been identified on a human-derived isolate of $S$. enteritidis, strain 27655 (Feutrier et al., 1986; Müller et al., 1991; Collison et al., 1991). The structural subunit of one type of fimbriae, of $M_{\mathrm{r}} 21000$, designated SEF21, shares significant Nterminal amino acid sequence homology with the structural subunit of type 1 fimbriae of $S$. typhimurium (Müller et al., 1991). The two other fimbriae, with structural subunits of $M_{\mathrm{r}}$ approximately 14000 and 17000, were designated SEF14 (Müller et al., 1991) [mistakenly identified as type 1 when first published (Feutrier et al., 1986)] and SEF17 (Collinson et al., 1991, 1992), respectively. The SEF17 fimbrial subunit shares $\mathrm{N}$-terminal amino acid sequence homology with the structural subunits of curli of Escherichia coli (Arnqvist et al., 1992).

As a first step toward establishing the relationship of SEFA with other fimbrial antigens within the Enterobacteriaceae and as an essential preliminary to determining its biological role, the gene encoding SEFA was to be identified from within an $S$. enteritidis gene library and its DNA nucleotide sequence determined.

\section{Methods}

Bacterial strains, plasmids and media. Wild-type Salmonella isolates were from the Salmonella reference laboratory, Central Veterinary Laboratory, and were stored on Dorset egg slopes. Escherichia coli strain $\mathrm{DH} 5 \alpha\left[\mathrm{F}^{-}\right.$endAI hsdRI $7\left(\mathrm{r}_{\mathrm{k}}^{-} \mathrm{m}_{\mathrm{k}}^{+}\right)$supE44 thi-1 $\lambda^{-}$recAl gyrA96 relAl $\Delta(\arg F-$ lac $Z Y A) U 169 \phi 80$ lac $Z \Delta M 15)$ ] (Life Technologies; Max Efficiency competent cells) was used as the recipient in transformation experiments, following the manufacturer's recommendations. LuriaBertani (LB) medium was used for growth of $E$. coli recombinants (Maniatis et al., 1982). Supplements added were ampicillin $\left(100 \mu \mathrm{g} \mathrm{ml}^{-1}\right.$, Pembritin, Beecham) and X-Gal $\left(40 \mu \mathrm{g} \mathrm{ml}^{-1}\right.$, Life Technologies). E. coli strain DS410 ( $\mathrm{F}^{-} \min A \min B$ thi ara gal $x y l$ mtl ton $A$ rps $L$ rec $A$ ) was the host for minicell experiments. Plasmid pUC18 (Life Technologies) was used as the standard cloning vector.

DNA extraction and S. enteritidis library preparation. Total genomic DNA was extracted from Salmonella enteritidis strain 1246/89 using the method of Goldberg \& Ohman (1984) and was further purified by $\mathrm{CsCl}$ density-gradient centrifugation following standard procedures (Sambrook et al., 1989). For plasmid isolation, the alkaline extraction procedure of Birnboim \& Doly, as described by Maniatis et al. (1982), was used for all preparations with the exception of the investigations on plasmid profiles of Salmonella, where the method of Kado \& Liu (1981) was used. Restriction endonucleases and T4 DNA ligase (Life Technologies) were used in accordance with the manufacturer's recommendations. Calf intestinal phosphatase (CIP, Boehringer Mannheim) was used to remove the $5^{\prime}$ phosphate from the linearized vector, when appropriate, following the manufacturer's recommendation. For preparation of the gene library, total genomic DNA from $S$. enteritidis strain $1246 / 89$ was partially digested with Sau3A following the methods described by Maniatis et al. (1982) and resolved by electrophoresis through low-gelling-temperature agarose (Nuseive, FMC, Rockland, ME, USA) in TAE buffer ( $40 \mathrm{~mm}$-Tris, $20 \mathrm{~mm}$ sodium acetate, 2 mM-EDTA pH 7.7). An agarose block containing DNA fragments of between $2 \mathrm{~kb}$ and $5 \mathrm{~kb}$ was excised from the gel and the DNA purified using Prep-A-Gene glass milk (Bio-Rad). The prepared DNA was ligated with vector plasmid pUC18 which was cut with BamHI and dephosphorylated. The $1 \mathrm{~kb}$ ladder (Life Technologies) was used as DNA size marker. Ligations were done at room temperature for $16 \mathrm{~h}$. E. coli strain $\mathrm{DH} 5 \alpha$ was used as the recipient for transformations.

DNA sequencing. Double-stranded DNA sequencing was done throughout using Sequenase version 2.0 (United States Biochemical Corporation). For each sequencing reaction, $3 \mu \mathrm{g}$ plasmid cDNA was denatured at $37^{\circ} \mathrm{C}$ for $30 \mathrm{~min}$ in $0.2 \mathrm{M}-\mathrm{NaOH}, 0.2 \mathrm{~mm}$-EDTA in a final volume of $20 \mu \mathrm{l}$. The solution was neutralized by addition of $8 \mu \mathrm{l} 5 \mathrm{M}$ ammonium acetate, $\mathrm{pH} 7 \cdot 5$, and DNA was precipitated by ethanol. The pellet was redissolved in $4 \mu 1$ distilled water. Sequencing reactions were done in accordance with the manufacturer's recommendations. Primers for sequencing were synthesized on an ABI PCR-mate following the maker's recommendations and were designed to give overlapping readings on both strands. The nucleotide sequences obtained were compiled and analysed using Microgenie software (Beckman Instruments) and the University of Wisconsin Genetics Computer Group (UWGCG) package at the SERC laboratory, Daresbury, UK.

Polymerase chain reaction (PCR). The methods of Saiki et al. (1985) were followed. Taq polymerase was supplied by Perkin-Elmer Cetus (Amplitaq) and dNTPs were supplied by Boehringer. Primers were synthesized as described above. For the amplification of the SEF14 structural subunit gene sequence (bases 13-572) the primers were $5^{\prime}$ GGGAATTCGTATATTAGCATCCGCAGA-3' (Psefa1) and 5'GGGAAGCTTTTGATACTGCTGAACGTAG-3' (Psefa3), with EcoRI and HindIII restriction sites (underlined). For amplification of the type 1 fimbrial subunit gene $(\operatorname{fimA})$, the primers were $5^{\prime}$ TTTGAATTCTGGTTAATGCAGCCTGTG-3' (Pfimal) and 5'TTTGGATCCTAAAGGAGGCGTCGGC-3' (Pfima2) (bases 476896) (Purcell et al., 1987) with EcoRI and BamHI sites to facilitate cloning of the amplified products. Target DNA was prepared from cells harvested by centrifuging $1.5 \mathrm{ml}$ of an overnight culture in LB broth. The pellet was resuspended in $200 \mu \mathrm{l} 10 \mathrm{~mm}$-Tris/ $\mathrm{HCl}, \mathrm{pH} 8 \cdot 0,1 \mathrm{~mm}$ EDTA, $150 \mathrm{~mm}-\mathrm{NaCl}$, vortexed thoroughly in an equal volume of buffered phenol/chloroform (Maniatis et al., 1982) and centrifuged at $13000 \mathrm{~g}$ for $5 \mathrm{~min}$. The upper aqueous phase was removed and the DNA precipitated by ethanol. The semipurified DNA pellet was resuspended in $200 \mu \mathrm{l} 10 \mathrm{~mm}$-Tris/ $\mathrm{HCl}, \mathrm{pH} 8.0,1 \mathrm{~mm}$-EDTA and $1 \mu \mathrm{l}$ samples were used for PCR. Saiki buffer was adjusted to $5.5 \mathrm{mm-}$ $\mathrm{MgCl}_{2}$. A thermal cycler (Hybaid, Middlesex, UK) was used and the conditions were $94{ }^{\circ} \mathrm{C}$ for $1.5 \mathrm{~min}$ (denaturing), $50^{\circ} \mathrm{C}$ for $1.5 \mathrm{~min}$ (annealing), $72{ }^{\circ} \mathrm{C}$ for $2.0 \mathrm{~min}$ (extension) for 30 cycles.

Cloning of PCR products. Amplified PCR products were subjected to agarose gel electrophoresis through Nusieve low-gelling-temperature agarose in TAE buffer and visualized after ethidium bromide staining (Maniatis et al., 1982) by UV transillumination (Ultraviolet Product Inc., San-Gabriel, CA, USA). Agarose gel blocks containing DNA products were excised and the DNA purified using Prep-A-Gene glass milk. Eluted DNA was digested to completion by relevant restriction endonucleases. The ligation in vector plasmid pUC18, and transformation into strain $\mathrm{DH} 5 \alpha$, were as described above.

Hybridization. Lysis of bacterial colonies and the capillary transfer of DNA species from agarose gels onto filters were done by the methods 
described by Maniatis et al. (1982). Preparation of radioisotopically labelled probe, hybridization conditions and post-hybridization washes were as described previously (Woodward et al., 1989).

IPTG induction. Overnight cultures grown in Casamino acid broth were diluted $1: 10$ in fresh medium and incubated at $37^{\circ} \mathrm{C}$ for $30 \mathrm{~min}$, before addition of IPTG $\left(20 \mu \mathrm{g} \mathrm{ml}^{-1}\right)$. After $2 \mathrm{~h}$ incubation, cultures were adjusted to an equivalent $\mathrm{OD}_{660}$, centrifuged, and the cell pellets were resuspended in loading buffer for PAGE.

Minicell analysis. E. coli strain DS410 harbouring plasmids was grown and minicells were prepared from it following the procedure described by Stocker et al. (1984). After resuspension in M9 minimal medium containing $30 \%(\mathrm{v} / \mathrm{v})$ glycerol to $\mathrm{OD}_{600} 2 \cdot 0$, which corresponds to approximately $2 \times 10^{10} \mathrm{cells} \mathrm{ml}^{-1}$, purified minicells were stored at $-70^{\circ} \mathrm{C}$. For labelling, $100 \mu \mathrm{l}$ of prepared minicells were preincubated at $37^{\circ} \mathrm{C}$ to eliminate mRNA encoding chromosomal gene products. Minicells were labelled with $\left[{ }^{35} \mathrm{~S}\right]$ methionine and the labelling reaction quenched with unlabelled L-methionine as recommended. Labelled cells were boiled in loading buffer (Laemmli, 1970) and polypeptides were separated by SDS-PAGE. Gels were either dried and autoradiographed for $16 \mathrm{~h}$ at room temperature or submitted to Western blotting (Towbin et al., 1979) as described below.

Immunoblotting procedure. Proteins from bacterial cultures grown overnight and from minicell preparations were separated on a denaturing $15 \%(\mathrm{w} / \mathrm{v})$ polyacrylamide gel as described by Laemmli (1970). Proteins were transferred to nylon-supported nitrocellulose membranes (Hybond-C Extra, Amersham) by the method of Towbin et al. (1979). Bacterial colonies grown on nitrocellulose membranes were lysed by exposure to a chloroform-saturated atmosphere. Membranes were blocked for $1 \mathrm{~h}$ in a solution of TPBS (0.01 M-PBS, pH 7.2, $0.05 \%$ Tween 20$)$ with $3 \%(\mathrm{w} / \mathrm{v})$ gelatin. Development was by an alkaline phosphatase detection system (Bio-Rad) with mAb 69/25 (Thorns et al., 1990) or a monospecific rabbit polyclonal antiserum (Thorns et al., 1992) as the primary antibody.

Immunoelectron microscopy (IEM). The binding of $\mathrm{mAb} 69 / 25$ and polyclonal rabbit serum specific for the SEF14 fimbrial antigen was as previously described (Thorns et al., 1990) using gold-labelled anti-Ig for detection.

Latex agglutination. Blue latex particles $(0.8 \mu \mathrm{m}$ Estapor, RhônePoulenc) were coated with antibodies following the procedure of Hechemy \& Michaelson as reported elsewhere (Thorns et al., 1992).

\section{Results}

\section{Cloning the SEF14 antigen gene}

Total genomic DNA from $S$. enteritidis strain 1246/89 was digested partially with Sau3A. Fragments $2-5 \mathrm{~kb}$ in size were ligated with BamHI-digested and dephosphorylated pUC18 DNA. The ligation mixture was used to transform $E$. coli strain DH5 $\alpha$. Recombinant colonies were replica-plated onto fresh agar medium and nylon-supported nitrocellulose membranes for immunoscreening using mAb69/25 specific for the SEFA fimbrial antigen. Of about 2500 recombinants screened, one strain, designated CT15, expressed the SEFA antigen. The recombinant plasmid, designated pVW400, was extracted from strain CT15 and analysed by restriction endonuclease digestion. The insert was de- termined to be $2.4 \mathrm{~kb}$ in size and convenient restriction sites within the cloned fragment were used to create a series of overlapping subclones by ligation with suitably prepared pUC18. The minimum-sized fragment capable of directing synthesis of the SEFA antigen, as determined by immuno-dotblot analysis of recombinant clones, was a 584 bp DraI fragment cloned into the $S m a$ I site of pUC18, giving recombinant plasmid pVW406.

\section{Nucleotide sequence analysis of SEF14 antigen gene}

The DNA nucleotide sequence of the DraI fragment is given, along with deduced amino acid sequence, in Fig. $1(a)$. An open reading frame was identified with two potential f-Met start codons (bases 46 and 79, Fig. 1a), giving putative protein products of 176 and 165 amino acid residues, respectively, with respective $M_{\mathrm{r}}$ values of 18000 and 16500 . A Shine-Dalgarno ribosome-binding consensus sequence, GGAGA, was located at position 65-69, exactly $9 \mathrm{bp}$ upstream of the second ATG start codon (position 79). The first ATG start codon (position 46) was located within a region showing the potential to form a significant hairpin loop secondary structure (positions 16-54) (Fig. 1b). The presence of a potential -10 promoter sequence, TATATTA, at positions 13-19 suggests that this region might be involved in promoting expression of the gene encoding the SEFA antigen, hereafter designated as $\operatorname{sef} A$. The DNA sequence was compared with those in the GenBank and EMBL databases but showed no significant homology with any described sequences. However, the deduced amino acid sequence shared significant homology with the $\mathrm{N}$ terminal amino acid sequence of a fimbrial antigen from $S$. enteritidis (Fig. 1a) originally described as type 1 by Feutrier et al. (1986) but renamed SEF14 by Müller $e t$ al . (1991).

\section{Minicell and Western blot analysis of recombinant plasmids}

Plasmids pVW406 and pUC18, into which the sef $A$ gene was cloned, were transformed in separate experiments into the $E$. coli minicell-producing strain DS410. Polypeptides encoded by these plasmids were labelled with $\left[{ }^{35}\right.$ S $]$ methionine and compared by SDS-PAGE and autoradiography. No polypeptide with an $M_{\mathrm{r}}(16500)$ compatible with that of a deduced sef $A$ gene product was observed, although the $\beta$-galactosidase major band was absent from the pVW406 experiment but present in the pUC18 control experiment (data not shown). To confirm expression of the SEF14 antigen, minicells containing pVW406 were subjected to Western blot analysis using the SEFA antigen-specific mAb $69 / 25$ as probe. Poly- 
(a)

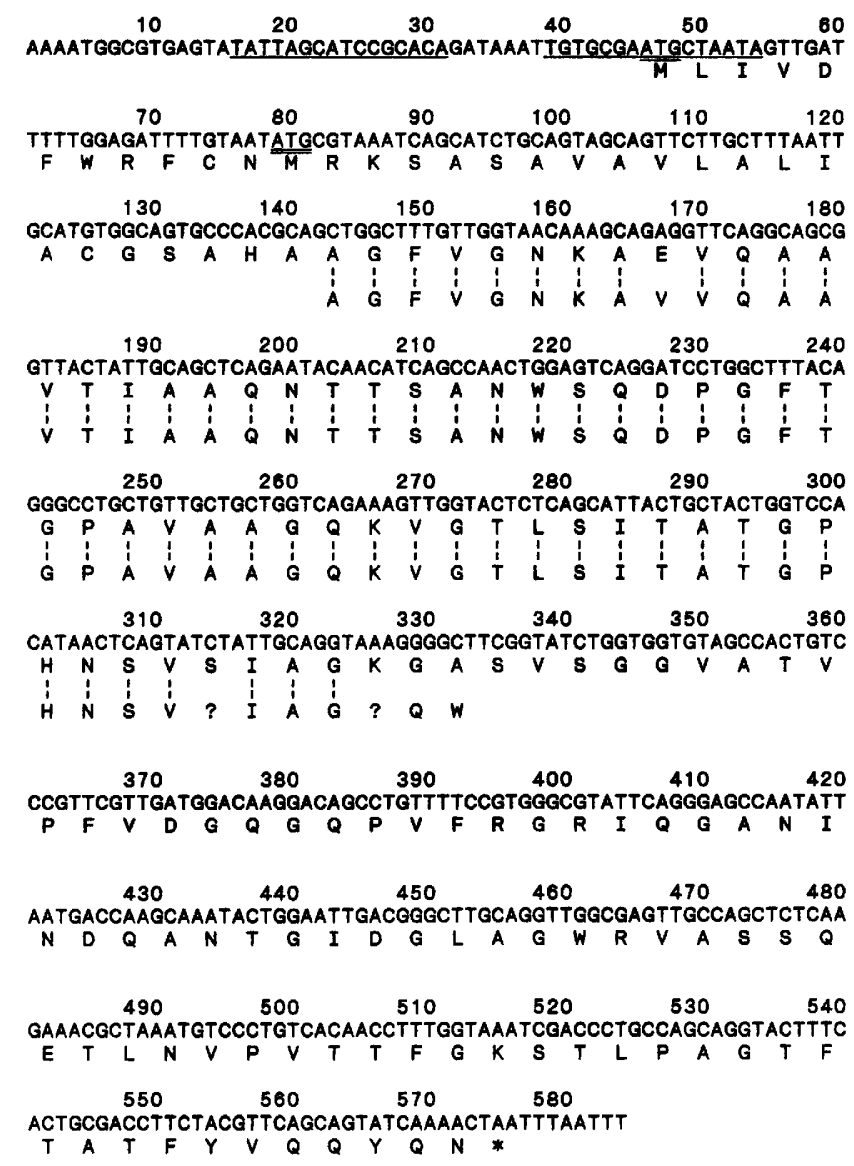

(b)

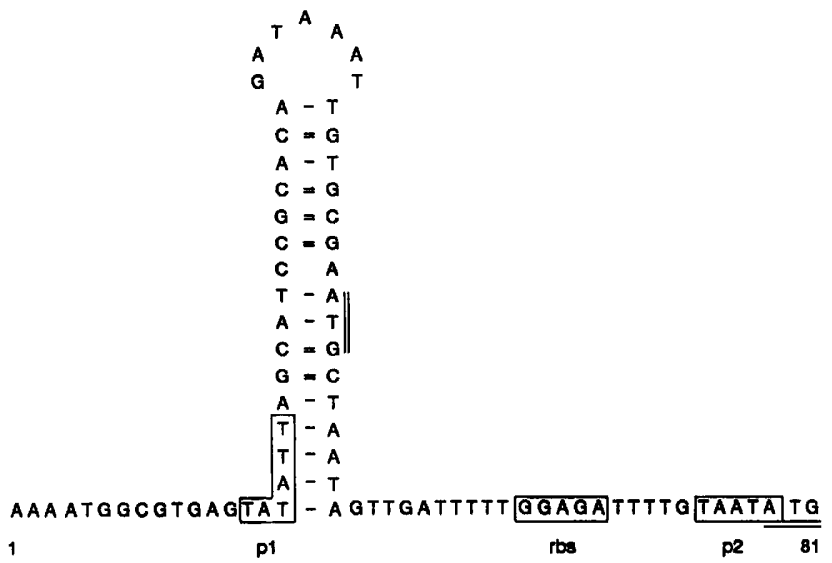

Fig. 1. (a) Nucleotide sequence of the 584 bp DraI DNA fragment encoding the SEF14 antigen, with the deduced amino acid sequence of the large open reading frame. The $\mathrm{N}$-terminal amino acid sequence determined chemically by Feutrier et al. (1986) is aligned. The two possible ATG $\mathrm{f}$-Met start codons are double-underlined and a region of potential secondary folding is single-underlined. (b) Potential secondary structure of the putative promoter region (1-81) is given along with potential -10 regions ( $\mathrm{pl}$ and $\mathrm{p} 2$, boxed), ribosome-binding site (rbs) and the two ATG f-Met start codons (double-underlined).

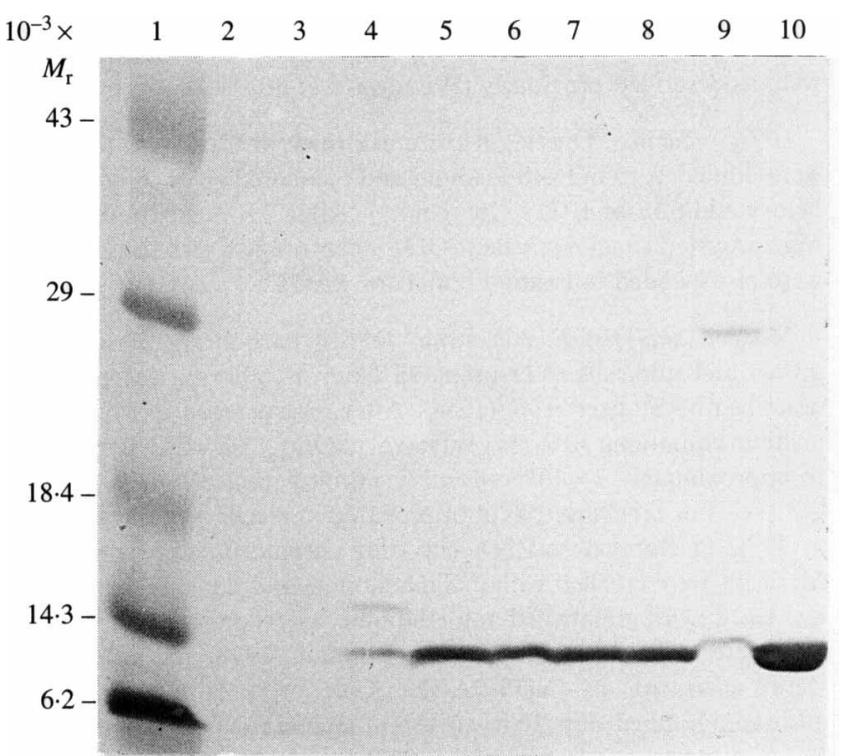

Fig. 2. Western blots of polypeptides expressed in $E$. coli recipients harbouring recombinant plasmids, using $\mathrm{mAb} 69 / 25$ as a probe to detect SEFA antigen. Lanes: $1, M_{\mathrm{r}}$ markers (Rainbow, Amersham); 2 , E. coli DH $5 \alpha$; 3, E. coli DH5 $\alpha$ (pUC18); 4, E. coli DS410 minicells harbouring pVW406; 5, E. coli $\mathrm{DH} 5 \alpha$ (pVW406) induced with IPTG; 6, E. coli DH5 $\alpha$ (pVW406), uninduced; 7, E. coli DH5 $\alpha$ (pVW400) induced with IPTG; 8, E. coli DH5 $\alpha$ (pVW400), uninduced; 9, $S$. enteritidis $1246 / 89 ; 10$, purified SEF14 fimbriae.

peptides with apparent $M_{\mathrm{r}}$ values of 14300 and 16000 were observed (Fig. 2, lane 4), suggesting the presence of both a mature subunit protein and its precursor in the minicells bearing pVW406. $E$. coli cells harbouring recombinant plasmids pVW400 and pVW406 were grown separately in Casamino acid broth with and without IPTG. Equivalent protein loadings from each culture were analysed by SDS-PAGE. Polypeptides were immunoblotted using mAb 69/25 (Fig. 2). No discernible differences in band intensity were observed. Sequence analysis of plasmids pVW400 and pVW406 (data not shown) demonstrated that the directions of transcription of the sef $A$ gene and of the $l a c Z$ gene of plasmid pUC18 were opposite in plasmid pVW400 but were the same in plasmid pVW406. Sequence analysis of three other derivatives of pUC18 with the sefA-bearing DraI fragment cloned into the $S m a I$ site, which had been selected on the basis of lac $Z$ inactivation and antigenreactive immuno-dotblots with $\mathrm{mAb} 69 / 25$, had the $l a c Z$ and sef $A$ genes in the same transcriptional orientation. IEM studies were done to test for the presence of the SEFA antigen on the cell surface of $E$. coli recombinants harbouring pVW400 and pVW406. No labelling was observed in these strains. However, the positive control $S$. enteritidis strain $1246 / 89$ was shown by IEM to produce both the SEFA fimbrial structure described by Thorns et al. (1990) and Müller et al. (1991), and 
fimbriae which did not label with mAb 69/25 which had a typical type 1 morphology.

\section{S. enteritidis encodes type 1 fimbriae homologous with those of $S$. typhimurium}

The presence of type 1-like fimbriae on S. enteritidis strain 1246/89 raised the question whether the gene encoding the structural subunit of those type 1-like fimbriae was homologous with that of $S$. typhimurium. Furthermore, it was essential to discriminate between the two fimbrial structures at the genetic level. To do this, PCR primers were synthesized using the published fimA sequence of the type 1 fimbrial structural subunit gene of S. typhimurium strain S850 (Purcell et al., 1987). PCR was used to amplify a $420 \mathrm{bp}$ intragenic fragment from fimA. The amplified product was cloned into $\mathrm{pUCl} 18$ and the DNA nucleotide sequence confirmed as identical with the published sequence. The same primers were used in PCR to amplify the internal fragment from $S$. enteritidis strain 1246/89. The PCR products from two separate experiments were cloned into pUC18 and four individual recombinant plasmids sequenced. Only five base differences were observed when the nucleotide sequences were compared with that of the $S$. typhimurium fimA fragment sequence (M. J. Woodward, A. M. Warner \& C. Turcotte, unpublished data).

\section{SEFA and type 1 fimbriae genes show distinct distribution patterns in salmonellae}

Individual isolates of 74 Salmonella serotypes representing 17 serogroups were tested by colony hybridization for the presence of sequences homologous with the sefA and fimA genes (Table 1). The DraI fragment isolated from pVW400 was radiolabelled and used as a probe in these experiments. Of the 1185 isolates tested, only $S$. blegdam, $S$. dublin, $S$. enteritids, $S$. gallinarum, S. moscow, S. pullorum, S. rostock, S. seremban and $S$. typhi, all belonging to serogroup D, hybridized with the sef $A$ probe (Table 1). To probe for type 1 fimbriae, the cloned $420 \mathrm{bp}$ PCR product from $S$. typhimurium was excised from the pUC18 vector, radiolabelled and used under stringent conditions as a gene probe to screen 273 salmonellae representative of 74 serotypes after colony lysis. The probe hybridized with all serotypes tested, supporting the generally held view that the $\operatorname{fim} A$ gene is ubiquitous among salmonellae.

The interesting distribution of the sefA gene could have been related to the presence of a plasmid. Therefore, to test the location of the sefA gene, Southern hybridization experiments were done using the $\operatorname{sef} A$ probe and, as a positive plasmid control, a probe derived from the virulence region of the $S$. dublin $75 \mathrm{kbp}$ plasmid
(Woodward et al., 1989). In separate experiments, each probe was hybridized with Southern transfers of plasmid profiles and of $E c o$ RI and $B g I I I$ digests of genomic DNA from various Salmonella serotypes which hybridized with the sef $A$ probe and from $S$. typhimurium as a SEFA fimbriae-negative control. The sefA gene probe hybridized only with the genomic DNA and the virulence region DNA probe hybridized only with the virulence plasmids. Interestingly, some restriction fragment length polymorphism was observed for the sef $A$ region in the probed chromosomal digests. For example, $B g / I I$ digests of genomic DNA from $S$. berta, S. blegdam, S. enteritidis, $S$. gallinarum and $S$. pullorum gave $18 \mathrm{~kb}$ fragments which hybridized with the $s e f A$ probe, whereas $S$. dublin and $S$. rostock on the one hand and $S$. seremban and $S$. typhi on the other gave hybridizing fragments of $16 \mathrm{~kb}$ and $24 \mathrm{~kb}$, respectively.

\section{Not all sef $A^{+}$isolates express the SEFA antigen}

Thorns et al. (1990) reported that all isolates of $S$. enteritidis and about $90 \%$ of $S$. dublin isolates expressed the SEFA antigen at the cell surface. However, the hybridization experiments (Table 1) indicated that other group D serotypes possessed the $s e f A^{+}$gene. Agglutination experiments using latex particles coated with $\mathrm{mAb} 69 / 25$ were done on 311 isolates of group $\mathrm{D}$ salmonellae which hybridized with the sef $A$ probe. Whilst all $S$. blegdam, $S$. enteritidis and $S$. moscow isolates and $93 \%$ of $S$. dublin isolates agglutinated, indicating surface presentation of the antigen, $S$. berta, $S$. gallinarum, $S$. pullorum, $S$. rostock, S. serembam and $S$. typhi did not (Table 1). Furthermore, Western blotting with mAb 69/25 and SEFA-monospecific polyclonal antisera of whole-cell lysates of single isolates of $S$. berta, $S$. gallinarum, $S$. pullorum, $S$. rostock, $S$. serembam and $S$. typhi did not give evidence of expression of the SEFA antigen either as a surface or cytoplasmic antigen. IEM confirmed the presence of the SEFA antigen as a fimbrialike structure on single isolates of $S$. blegdam and $S$. moscow, four isolates of $S$. enteritidis and four isolates of $S$. dublin which agglutinated latex particles coated with $\mathrm{mAb} 69 / 25$.

\section{The sef A gene is conserved}

It was possible that the SEFA antigen displayed antigenic heterogeneity which might explain the inability to detect antigen expression using the available immunological reagents on some of those isolates which hybridized with the sef $A$ gene probe. To test this, PCR was used to amplify the sef $A$ gene from single isolates of $S$. gallinarum and $S$. pullorum which were negative in the latex agglutination and Western blotting experiments. For 
Table 1. Salmonella strains examined by hybridization with sefA and fimA gene probes and by latex agglutination for surface expression of sef $A$ gene product

The results are shown as the number of probe-positive isolates over the number of isolates tested. For $\operatorname{sef~}^{+}$, the values in parentheses are the number of latex-positive isolates over the number of isolates tested. ND, Not done.

\begin{tabular}{|c|c|c|c|}
\hline Serogroup & Serotype & $\operatorname{sef} A \dagger$ & $\operatorname{fim} A^{\dagger}$ \\
\hline B & $\begin{array}{l}\text { S. agama } \\
\text { S. agona } \\
\text { S. bredeney } \\
\text { S. derby } \\
\text { S. heidelberg } \\
\text { S. indiana } \\
\text { S. reading } \\
\text { S. schwarzengrund } \\
\text { S. stanley } \\
\text { S. typhimurium }\end{array}$ & $\begin{array}{l}0 / 1 \\
0 / 10 \\
0 / 10 \\
0 / 9 \\
0 / 11 \\
0 / 1 \\
0 / 2 \\
0 / 1 \\
0 / 5 \\
0 / 264\end{array}$ & $\begin{array}{l}1 / 1 \\
1 / 1 \\
1 / 1 \\
1 / 1 \\
1 / 1 \\
1 / 1 \\
1 / 1 \\
1 / 1 \\
1 / 1 \\
64 / 64\end{array}$ \\
\hline $\mathrm{Cl}$ & $\begin{array}{l}\text { S. bareilly } \\
\text { S. infantis } \\
\text { S. lille } \\
\text { S. livingstone } \\
\text { S. mbandaka } \\
\text { S. montevideo } \\
\text { S. ohio } \\
\text { S. oranienburg } \\
\text { S. oslo } \\
\text { S. tennessee } \\
\text { S. thompson } \\
\text { S. virchow }\end{array}$ & $\begin{array}{l}0 / 1 \\
0 / 12 \\
0 / 1 \\
0 / 9 \\
0 / 9 \\
0 / 8 \\
0 / 6 \\
0 / 1 \\
0 / 1 \\
0 / 6 \\
0 / 4 \\
0 / 31\end{array}$ & $\begin{array}{l}1 / 1 \\
1 / 1 \\
1 / 1 \\
1 / 1 \\
1 / 1 \\
1 / 1 \\
1 / 1 \\
1 / 1 \\
1 / 1 \\
1 / 1 \\
1 / 1 \\
24 / 24\end{array}$ \\
\hline $\mathrm{C} 2$ & $\begin{array}{l}S . \text { goldcoast } \\
S . \text { hadar } \\
S . \text { newport }\end{array}$ & $\begin{array}{l}0 / 1 \\
0 / 9 \\
0 / 10\end{array}$ & $\begin{array}{l}1 / 1 \\
1 / 1 \\
1 / 1\end{array}$ \\
\hline $\mathrm{C} 3$ & $\begin{array}{l}\text { S. albany } \\
\text { S. kentucky } \\
\text { S. tado }\end{array}$ & $\begin{array}{l}0 / 1 \\
0 / 2 \\
0 / 1\end{array}$ & $\begin{array}{l}1 / 1 \\
1 / 1 \\
1 / 1\end{array}$ \\
\hline D1 & $\begin{array}{l}\text { S. berta } \\
\text { S. blegdam } \\
\text { S. canastel } \\
\text { S. dublin } \\
\text { S. durban } \\
\text { S. eastbourne } \\
\text { S. enteritidis } \\
\text { S. gallinarum } \\
\text { S. kapemba } \\
\text { S. miami } \\
\text { S. moscow } \\
\text { S. napoli } \\
\text { S. panama } \\
\text { S. pullorum } \\
\text { S. rostock } \\
\text { S. seremban } \\
\text { S. typhi } \\
\text { S. wangata }\end{array}$ & $\begin{array}{c}1 / 1(0 / 1) \\
1 / 1(1 / 1) \\
0 / 1 \\
216 / 216(93 / 100) \\
0 / 1 \\
0 / 1 \\
382 / 382(150 / 150) \\
44 / 44(0 / 44) \\
0 / 1 \\
0 / 1 \\
1 / 1 \\
0 / 1 \\
0 / 1 \\
12 / 12(0 / 12) \\
1 / 1(0 / 1) \\
1 / 1(0 / 1) \\
1 / 1(0 / 1) \\
0 / 1\end{array}$ & $\begin{array}{c}1 / 1 \\
\mathrm{ND} \\
1 / 1 \\
31 / 31 \\
1 / 1 \\
\mathrm{ND} \\
52 / 52 \\
42 / 42 \\
\mathrm{ND} \\
\mathrm{ND} \\
1 / 1 \\
\mathrm{ND} \\
\mathrm{ND} \\
3 / 3 \\
1 / 1 \\
\mathrm{ND} \\
\mathrm{ND} \\
1 / 1\end{array}$ \\
\hline D2 & $\begin{array}{l}\text { S. fresno } \\
\text { S. ouakam } \\
\text { S. plymouth } \\
\text { S. strasbourg }\end{array}$ & $\begin{array}{l}0 / 1 \\
0 / 1 \\
0 / 1 \\
0 / 1\end{array}$ & $\begin{array}{l}\text { ND } \\
1 / 1 \\
\text { ND } \\
\text { ND }\end{array}$ \\
\hline E1 & $\begin{array}{l}\text { S. anatum } \\
\text { S. give } \\
\text { S. lexington } \\
\text { S. london } \\
\text { S. meleagridis }\end{array}$ & $\begin{array}{l}0 / 9 \\
0 / 1 \\
0 / 1 \\
0 / 1 \\
0 / 9\end{array}$ & $\begin{array}{l}1 / 1 \\
1 / 1 \\
1 / 1 \\
1 / 1 \\
1 / 1\end{array}$ \\
\hline
\end{tabular}

Table 1. (cont.)

\begin{tabular}{clll}
\hline \hline Serogroup & \multicolumn{1}{c}{ Serotype } & sefA $\dagger$ & fimA $\dagger$ \\
\hline & S. nchanga & $0 / 1$ & $1 / 1$ \\
& S. orion & $0 / 7$ & $1 / 1$ \\
& S. binza & $0 / 9$ & $1 / 1$ \\
& S. drypool & $0 / 1$ & $1 / 1$ \\
& S. manila & $0 / 1$ & $1 / 1$ \\
& S. newington & $0 / 1$ & $1 / 1$ \\
E3 & S. thomasville & $0 / 8$ & $1 / 1$ \\
E4 & S. senftenberg & $0 / 9$ & $1 / 1$ \\
& S. taksony & $0 / 9$ & $1 / 1$ \\
F & S. aberdeen & $0 / 1$ & $1 / 1$ \\
G1 & S. havana & $0 / 1$ & $1 / 1$ \\
G2 & S. ajiobo & $0 / 1$ & $1 / 1$ \\
& S. kedougou & $0 / 10$ & $1 / 1$ \\
& S. worthington & $0 / 1$ & $1 / 1$ \\
$\mathrm{~K}$ & S. cerro & $0 / 1$ & $1 / 1$ \\
$\mathrm{~N}$ & S. urbana & $0 / 1$ & $1 / 1$ \\
$\mathrm{~N}$ & S. adelaide & $0 / 1$ & $1 / 1$ \\
& S. ealing & $0 / 1$ & $1 / 1$ \\
\multirow{2}{*}{$\mathrm{T}$} & S. gera & $0 / 1$ & $1 / 1$ \\
& & &
\end{tabular}

each isolate, PCR using primers Psefa 1 and Psefa3 was carried out on a separate occasion to avoid the possibility of cross-contamination. S. typhimurium was used as a negative control. PCR-amplified DNA products of $560 \mathrm{bp}$ were obtained from both $S$. gallinarum and $S$. pullorum but not $S$. typhimurium. The 560 bp DNA products derived from $S$. gallinarum and $S$. pullorum were cloned into pUC18 (see Methods), again in separate experiments performed on different occasions, and recombinant clones were identified by colony blot hybridization using the DraI sef $A$ gene probe. From each of the two cloning experiments, plasmid DNA from three individual recombinants was extracted and the DNA nucleotide sequences of the cloned PCR inserts were determined by double-stranded sequencing. The six DNA sequences, three from each of the serotypes tested, $S$. gallinarum and $S$. pullorum, were identical to the sequence determined for sefA in pVW406. Similar experiments using one SEFA-expressing and one SEFAnon-expressing $S$. dublin as templates for PCR also gave identical sef $A$ DNA nucleotide sequences.

\section{Discussion}

The mAb 69/25 described by Thorns et al. (1990) was used to detect expression of the gene encoding the SEF14 antigen from within a $S$. enteritidis pUC gene library. Nucleotide sequence analysis of the minimum DNA fragment allowing expression of the antigen (plasmid 
pVW406) identified an open reading frame with two potential f-Met translational start codons, both in the same frame, yielding theoretical translation products of $M_{\mathrm{r}} 18000$ and 16500 . Western blot analysis of minicells harbouring pVW406 gave clear evidence for posttranslational processing because two polypeptide products of about $M_{\mathrm{r}} 16000$ and $M_{\mathrm{r}} 14300$ were detected, the latter having the same $M_{\mathrm{r}}$ as the mature fimbrial subunit protein isolated from $S$. enteritidis. It thus seems likely that the precursor form of the SEFA subunit arises by translation from the second f-Met codon. The lack of ${ }^{35} \mathrm{~S}$ incorporation into the polypeptides in the minicell experiments may reflect the presence of the single $\mathrm{N}$ terminal methionine residue which was likely to be cleaved early during processing.

The location of a Shine-Dalgarno site exactly $9 \mathrm{bp}$ upstream of the second f-Met start codon supports the hypothesis that this was the translational start codon. As with other secreted proteins, the deduced N-terminal sequence was hydrophobic, a property common for signal sequences (Silhavy et al., 1983). A number of potential peptidase cleavage sites (Stormo, 1986; Oliver, 1987) were present. An Ala-X-Ala peptidase cleavage motif (Oliver, 1987) was observed in the deduced amino acid sequence immediately before a $\mathrm{N}$-terminal amino acid sequence determined chemically by Feutrier et al. (1986). The recombinant SEFA antigen had the same $M_{\mathrm{r}}$ as the native antigen either extracted biochemically or obtained from cell lysis of $S$. enteritidis, suggesting that post-translational processing in $E$. coli and $S$. enteritidis was the same. Our results confirm and add to the information obtained by Feutrier et al. (1986) and more recently Müller et al. (1991) concerning the nature of this $S$. enteritidis fimbrial antigen; hereafter we refer to the antigen as SEF14 following the nomenclature of Müller et al. (1991).

The screening of the $S$. enteritidis pUC gene library with $\mathrm{mAb} 69 / 25$ was successful because the antigen was expressed in $E$. coli. Sequences upstream of the sef $A$ gene in $\mathrm{pVW} 400$ contained potential RNA polymerase -10 sites, although no -35 consensus site was identified. Expression appeared to be independent of the inducible lacZ system, suggesting that expression of sef $A$ was regulated by its own promoter at least in pVW400. Sequences homologous with other known regulatory regions were not identified. SEF14 antigen expression in $S$. enteritidis is dependent upon a number of environmental factors (Thorns et al., 1992), in common with expression of other well-characterized fimbriae (De Graaf et al., 1980; Van Verseveld et al., 1985; De Graaf \& Mooi, 1986). A region of significant secondary structure overlapping one potential -10 site was observed. Interestingly, similar 'hairpin' regulatory sequences have been described for other fimbrial antigen genes (Klemm, 1984; De Graaf \& Mooi, 1986). This structure may be involved in sefA gene regulation or it may be a rho-dependent stop signal (Yagger \& Von Hippel, 1987) of the preceding gene. Without further upstream DNA nucleotide sequence and transcription studies, comments on regulation of sefA expression would be speculative. Expression of SEF14 antigen from pVW400 may have been driven by spurious promoter sites in the pUC vector. In pVW406, however, expression of sefA should have been dependent on the lac $Z$ promoter of pUC18, although no clear evidence for this was gained by IPTG induction experiments.

The limited distribution of sefA within group D salmonellae is interesting. Southern hybridization data indicated a chromosomal location for sef $A$, suggesting that the limited distribution pattern was not primarily a consequence of the presence or absence of a plasmid. The apparent inability of some strains to express the antigen as a surface structure, assuming that latex agglutination is an adequate means of testing this, raises questions as to the genetic and physiological competence of these strains to do so. That $E$. coli recombinants did not express the antigen on the cell surface, as tested by IEM, was not unexpected because they probably lacked ancillary genes essential for biogenesis, as described for other fimbrial antigens within the Enterobacteriaceae (Orndorff \& Falkow, 1984; De Graaf \& Klaasen, 1986; Klemm \& Christiansen, 1990). Expression of the SEF14 antigen as a surface structure was detected only in $S$. enteritidis, S. dublin, S. blegdam and S. moscow, although the $\operatorname{sef} A$ gene was present in other group D salmonellae. The nucleotide sequence of sefA homologues in individual isolates of $S$. dublin, $S$. gallinarum and $S$. pullorum which did not express the SEF14 antigen was identical to that of $S$. enteritidis, suggesting that lack of antigen detection was not a result of antigenic heterogeneity. In latex agglutination tests with $S$. dublin, 93 out of 100 isolates gave the typical positive reaction seen with $S$. enteritidis. It is possible that the seven nonreacting isolates did not produce the antigen or that its detection was masked by the presence of capsular antigen. In IEM of $S$. enteritidis not all bacteria labelled with $\mathrm{mAb} 69 / 25$, which suggested that not all cells in a population express the SEF14 antigen. Further genetic analysis is required to understand why certain serotypes of group D salmonellae possessed sefA but failed to express SEF14 antigen either as a cytoplasmic antigen or as a fimbrial structure and to understand what modulates antigen expression.

Questions arise as to the significance of the SEF14 antigen in the biology of $S$. enteritidis, particularly whether it may play a role as a virulence factor. Insertion mutants unable to express SEF14 fimbriae may help to answer some of these questions. 
The authors wish to acknowledge helpful discussion with C. J. Thorns and Professor I. Smith, technical assistance from Anne Warner and Ian McLaren, the help of $\mathrm{Mr} \mathrm{A}$. C. Scott with the electron microscope work, and Dr G. Dougan for the gift of S. typhi DNA. C.T. is a visiting fellow from the Ministry of Agriculture, Animal Diseases Research Institute, PO Box 11300, Station ' $H$ ', Nepean, Ontario K2H 8P9, Canada.

\section{References}

Arnqvist, A., Olsén, A., Pfeifer, J., Russell, D. G. \& Normark, S. (1992). The Crl protein activates cryptic genes for curli formation and fibronectin binding in Escherichia coli HB101. Molecular Microbiology 6, 2443-2452.

Abraham, S. N., Sun, D., Vale, K. V. \& Beachey, E. H. (1988). Conservation of the D-mannose-adhesion protein among type-1 fimbriated members of the family Enterobacteriaceae. Nature, London 336, 682-684.

Buchanan, K., Falkow, S., Hull, R. A. \& Hull, S. I. (1985) Frequency among Enterobacteriacae of the DNA sequences encoding type 1 pili. Journal of Bacteriology 162, 799-803.

CleGG, S. \& Gerlach, G. F. (1987). Enterobacterial fimbriae. Journal of Bacteriology 169, 934-938.

Clegg, S., Purcell, B. K. \& Pruckler, J. (1987). Characterization of genes encoding type 1 fimbriae of Klebsiella pneumoniae, Salmonella typhimurium, and Serratia marcescens. Infection and Immunity 55, 281-287.

Collinson, S. K., Emödy, L., MülleR, K.-H., Trust, T. J. \& Kay, W. W. (1991). Purification and characterization of thin, aggregative fimbriae from Salmonella enteritidis. Journal of Bacteriology 173, 4773-4781.

Collinson, S. K., Emödy, L., Trust, T. J. \& KaY, W. W. (1992). Thin aggregative fimbriae from diarrheagenic Escherichia coli. Journal of Bacteriology 174, 4490-4495.

De GraAF, F. K. \& KLAaSEN, P. (1986). Organization and expression of genes involved in the biosynthesis of 987P fimbriae. Molecular and General Genetics 204, 75-81.

De GraAF, F. K. \& MooI, F. R. (1986). The fimbrial adhesins of Escherichiae coli. Advances in Microbial Physiology 28, 65-143.

De Graaf, F. K., Klaasen-Boor, P. \& Van Hees, J. E. (1980). Biosynthesis of the K99 surface antigen is repressed by alanine. Infection and Immunity 30, 125-128.

DuGUID, J.P. \& OLD, D. C. (1980). Adhesive properties of Enterobacteriaceae. In Bacterial Adherence, Receptors and Recognition, Series B, vol. 6, pp. 185-218. Edited by E. H. Beachey. London: Chapman \& Hall.

Duguid, J. P., Anderson, E. S. \& Campbell, I. (1966). Fimbriae and adhesive properties in salmonellae. Journal of Pathology and Bacteriology 92, 107-138.

Duguid, J. P., Dareker, M. R. \& WheAter, D. W. F. (1976). Fimbriae and infectivity in Salmonella typhimurium. Journal of Medical Microbiology 9, 459-473.

Feutrier, J., Kay, W. W. \& Trust, T. J. (1986). Purification and characterization of fimbriae from Salmonella enteritidis. Journal of Bacteriology 168, 221-227.

Finlay, B. B. \& FalKow, S. (1989). Common themes in microbial pathogenicity. Microbiological Reviews 53, 210-230.

GoldBerG, J. B. \& OHMAN, D. E. (1984). Cloning and expression in Pseudomonas aeruginosa of a gene involved in the production of alginate. Journal of Bacteriology 158, 1115-1121.

Hornick, D. B., Allen, B. L., Horn, M. A. \& ClegG, S. (1991). Fimbrial types among respiratory isolates belonging to the family Enterobacteriaceae. Journal of Clinical Microbiology 29, 1795-1800.

JoHNSON, J. R. (1991). Virulence factors in Escherichia coli urinary tract infection. Clinical Microbiology Reviews 4, 80-128.

KaDO, C. I. \& LiU, S.-T. (1981). Rapid procedure for detection and isolation of large and small plasmids. Journal of Bacteriology 145, 1365-1373

KLEMM, P. (1984). The fimA gene encoding the type 1 fimbrial subunit of Escherichia coli, nucleotide sequence and primary structure of the protein. European Journal of Biochemistry 143, 395-399.

KLEMM, P. \& Christiansen, G. (1990). The fimD gene required for cell surface localization of Escherichia coli type 1 fimbriae. Molecular and General Genetics 220, 224-338.

Korhonen, T. K., Väisänen, V., Kallio, P., Nurmiaho-lassila, E. L., Ranta, H., Sittonen, A., Elo, J., Svenson, S. B. \& SvanborgEDÉN, C. (1982). The role of pili in the adhesion of Escherichia coli to human urinary tract epithelial cells. Scandinavian Journal of Infectious Diseases 33, 26-31.

KROGFELT, K. A. (1991). Bacterial adhesion: genetics, biogenesis and role in pathogenesis of fimbrial adhesins of Escherichia coli. Reviews of Infectious Diseases 13, 721-735.

LAEMMLI, U. K. (1970). Cleavage of structural proteins during the assembly of the head of bacteriophage T4. Nature, London 227 , 221-227.

Maniatis, T., Fritsch, E. F. \& SambrooK, J. (1982). Molecular Cloning: a Laboratory Manual. Cold Spring Harbor, NY: Cold Spring Harbor Laboratory.

Müller, K.-H., Collinson, S. K., Trust, T. J. \& Kay, W. W. (1991). Type 1 fimbriae of Salmonella enteritidis. Journal of Bacteriology 173 $4765-4772$.

NowotarsKa, M. \& MulczyK, M. (1977). Serologic relationship of fimbriae among the Enterobacteriaceae. Archivum Immunologiae Therapiae Experimentalis 25, 7-16.

Old, D. C. \& ADEGBOLA, R. A. (1985). Antigenic relationship among type-3 fimbriae of Enterobacteriaceae revealed by immunoelectronmicroscopy. Journal of Medical Microbiology 20, 113-121.

OlIVER, D. B. (1987). Periplasm and protein secretion. In Escherichia coli and Salmonella typhimurium: Cellular and Molecular Biology, pp. 56-69. Edited by F. C. Neidhardt and others. Washington, DC: American Society for Microbiology.

ORNDORFF, P. E. \& FALKOW, S. (1984). Organization and expression of genes responsible for type 1 piliation in Escherichia coli. Journal of Bacteriology 159, 736-744.

ParRY, S. H. \& RoOKe, D. M. (1985). Adhesins and colonization factors of Escherichia coli. In The Virulence of Escherichia coli: Reviews and Methods (Special Publication of the Society for General Microbiology), pp. 79-155. Edited by M. Sussman. New York \& London: Academic Press.

Pearce, W. A. \& Buchanan, T. M. (1980). Structure and cell membrane-binding properties of bacterial fimbriae. In Bacterial Adherence, Receptors and Recognition, Series B, vol. 6, pp. 289-344. Edited by E. H. Beachey. London: Chapman \& Hall.

Purcell, B. K., Pruckler, J. \& ClegGg, S. (1987). Nucleotide sequences of the genes encoding type 1 fimbrial subunits of Klebsiella pneumoniae and Salmonella typhimurium. Journal of Bacteriology 169, 5831-5834.

Saiki, R. K., Scharf, S., Faloona, F., Mullis, K. B., Horn, G. T., ERLICH, H. A. \& ARNHEIM, N. (1985). Enzymatic amplification of $\beta$ globin genomic sequences and restriction site analysis for diagnosis of sickle cell anemia. Science 230, 1350-1354.

SALIT, I. E. \& GotsCHLICH, E. C. (1977). Haemagglutination by purified type 1 Escherichia coli pili. Journal of Experimental Medicine 146, 1168-1181.

Sambrook, J., Fritsch, E. F. \& Maniatis, T. (1989). Molecular Cloning: a Laboratory Manual, 2nd edn. Cold Spring Harbor, NY: Cold Spring Harbor Laboratory.

Silhavy, T. J., Benson, S. A. \& EmR, S. D. (1983). Mechanisms of protein localization. Microbiological Reviews 47, 313-344.

Stocker, N. G., Pratt, J. M. \& Holland, I. B. (1984). In vivo gene expression in procaryotes. In Transcription and Translation, a Practical Approach, pp. 164-171. Edited by B. D. Hames \& S. J. Higgins. Oxford: IRL Press.

STORMO, G. (1986). Translation initiation. In Maximising Gene Expression, pp. 195-224. Edited by W. Reznikoff \& M. Gold. Stoneham, Mass.: Butterworth.

Tesh, V. L. \& O'BRIEN, A. D. (1992). Adherence and colonization mechanisms of enteropathogenic and enterohemorrhagic Escherichia coli. Microbial Pathogenesis 12, 245-254.

Thorns, C. J., Sojka, M. G. \& Chasey, D. (1990). Detection of a novel 
structure on the surface of Salmonella enteritidis by using a monoclonal antibody. Journal of Clinical Microbiology 28, 2409-2414.

Thorns, C. J., Sojka, M. G., Mclaren, I. M. \& Dibb-Fuller, M. (1992). Characterization of monoclonal antibodies against a fimbrial structure of salmonellae and certain other serotypes of group D salmonellae and their application as serotyping agents. Research in Veterinary Science 53, 300-308.

Towbin, H., STAEHELIN, T. \& Gordon, J. (1979). Electrophoretic transfer of proteins from polyacrylamide gels to nitrocellulose sheets. Proceedings of the National Academy of Science of the United States of America 76, 4350-4354.
Van Verseveld, H. W., Bakker, P., Van der Woude, T., Terleth, C. \& DE GRAAF, F. K. (1985). Production of fimbrial adhesins K99 and F41 by enterotoxigenic Escherichia coli as a function of growth-rate domain. Infection and Immunity 49, 159-163.

WoOdward, M. J., McLaren, I. \& Wray, C. (1989). Distribution of virulence plasmids within salmonellae. Journal of General Microbiology 135, 503-511.

YAGGER, T. D. \& VoN HIPPEL, P. H. (1987). Transcript elongation and termination in Escherichia coli. In Escherichia coli and Salmonella typhimurium: Cellular and Molecular Biology, pp. 1241-1275. Edited by F. C. Neidhardt and others. Washington, DC: American Society for Microbiology. 